\title{
Ostrich Meat: Nutritional, Breeding, and Consumption Aspects. The Case of Spain
}

\author{
F. Xavier Medina, Alicia Aguilar* \\ Department of Health Sciences, Universitat Oberta de Catalunya / Open University of Catalonia, UOC, Barcelona, Spain \\ *Corresponding author: aaguilarmart@uoc.edu
}

Received May 07, 2014; Revised June 05, 2014; Accepted June 11, 2014

\begin{abstract}
The consumption of ostrich meat was introduced into Europe in a relatively short time. Considered even today as an exotic meat, its inclusion in the usual sources of animal protein in our context has been repeatedly assessed, because it converge some of the benefits of poultry and red meat. Although information on their nutritional value is still limited, we have more data showing protein values quite similar to other meats but with a smaller proportion of histidine and serine; fat values close to poultry meat low in fat; cholesterol values similar to beef or chicken, and a healthy lipid profile. However, much research is needed on the effects of regular consumption of this meat and its general effects on the body and some social obstacles still need to be overcome before it becomes part of people's regular diet.
\end{abstract}

Keywords: food preferences, ostrich meat, nutritional value, consumption, Struthioniformes

Cite This Article: F. Xavier Medina, and Alicia Aguilar, "Ostrich Meat: Nutritional, Breeding, and Consumption Aspects. The Case of Spain.” Journal of Food and Nutrition Research, vol. 2, no. 6 (2014): 301305. doi: 10.12691/jfnr-2-6-6.

\section{Introduction}

At present, the increase in chronic diseases related to eating habits deemed unsuitable in public health circles, including an excessive intake of animal products, fats and processed foods, has led different international institutions and bodies to advocate eating more food originating from plants and prioritizing the consumption of protein sources low in saturated fat, such as pulses, fish, poultry and eggs $[1,2,3,4]$. This is because eating too much meat, particularly that of the red variety, has been linked with certain health problems, such as cardiovascular diseases $[5,6,7]$ and cancer $[8,9]$.

But historically, red meat has been particularly important in practical terms in times of plenty [10] and it has also had great symbolic significance in times of scarcity, when circumstances have prevented its consumption for one reason or another.

Additionally, it should not be forgotten that red meat is an excellent source of high biological value protein, easily absorbed iron and vitamin B12; nor that for a time, particularly after World War II, different European countries sought to prevent protein deficiencies and anaemia through food policies that led to a huge increase in red meat production [1].

The changes affecting meat consumption in our societies are decidedly complex, and are closely related to consumer perceptions and values that have been slowly developing over recent decades [11]. Meat remains extremely popular, despite moderating its consumption for health reasons (especially in the case of red meat) having been widely recommended. As Briz and de Felipe [12] noted in relation to data from a survey carried out in 1990, "(...) most consumers feel that (red) meat is not readily replaceable, being an essential part of good nutrition”.

It therefore comes as no surprise that, despite not being one of the cheapest or "healthiest" kinds of food, meat is as present and popular as ever in shopping baskets. Data on consumption and statistics on expenditure on food and drink both show that meat is one of the most in-demand products among individuals [13]. In the European Union (EU), the average level of meat, dairy product and fish consumption has risen markedly over the last 50 years, and has come to double the worldwide average [14]. The level of consumption of meat products in EU countries has remained at more than $60 \mathrm{~kg}$ per person over the last 20 years, and could rise to $69 \mathrm{~kg}$ in 2018 [15]. In the case of Spain, in nutritional terms, meat and its products are the main source of calories in the diet (contributing 17\% of total energy) and are also the major contributor to protein intake (28\%) and the second to the contribution of fat (23\% of daily fat ingested) [16].

In the light of this complex situation, attempts have been made over the last decade to seek healthier sources of animal protein so as to reconcile the need to adapt to new nutrition recommendations with the eating habits of Europeans, who are accustomed to a high level of meat consumption. It is in that context that ostrich, which first appeared on the Spanish market (and in Europe in general) at the beginning of 2000, during the BSE (Bovine Spongiform Encephalopathy) or "mad cow disease" crisis, may be able to carve itself a niche and become part of some citizens' regular diet. 
Actually, studies carried out to date on the nutritional composition of ostrich meat describe it as a product of high value in nutritional and dietary terms [17] but there are still important issues to solve before considering its possible recommendation from the standpoint of public health or including this meat in the usual, even recommended, patterns of consumption.

The aim of this article is to review and provide updated information on the consumption and nutritional value of this type of meat including a sociocultural perspective that should be considered when attempting to incorporate a new food element in the everyday diet of the population.

\section{Methodology}

For the nutritional composition of ostrich meat a search was conducted for articles published prior to July 2013 in major databases: MEDLINE, IME - Biomedicine (CSCI), Cochrane Library Plus, Informa Healthcare, and SpringerLink. The search was limited to studies published in English and Spanish, using combinations of the following keywords: “ostrich”, "meat”, “consumption”, "Struthioniformes", and "nutritional value". Also, we used bibliographic references included in the selected articles for review. For the consumption and production data, we consulted the official data of the different ministery or supranational organisations.

\section{Results}

\subsection{Ostrich Meat's Physical Characteristics and Nutritional Composition}

Despite its avian nature, ostrich meat is reddish in colour (similar to beef) due to a high concentration of pigment (22-30 $\mu \mathrm{g} \mathrm{Fe/g)} \mathrm{and} \mathrm{myoglobin} \mathrm{levels} \mathrm{closer} \mathrm{to}$ those found in mammals' muscles than in poultry $[18,19]$. Its flavour is not unlike that of beef, although it has a slightly fishy aroma, and it is tenderer and easier to digest due to its lower levels of intramuscular fat and collagen [17].

While knowledge of ostrich meat's nutritional composition is still limited, Majewska's recent studies [20] on 10 different types of muscle give the values set out below.

Table 1. Chemical composition (g/100 g of edible material) of ostrich meat

\begin{tabular}{|l|l|}
\hline Component & Ostrich meat \\
\hline Dry material & $23.3-25.5$ \\
\hline Protein & $20.6-21.7$ \\
\hline Fat & $0.9-1.34$ \\
\hline Ash & $1.07-1.17$ \\
\hline $\begin{array}{l}\text { Source: Majewska et al. (2009). Variation depends on the muscle } \\
\text { analyzed and the bird's age }\end{array}$
\end{tabular}

Ostrich meat's percentage of protein (20.6-21.7\%) and its amino acid composition are rather similar to those of meats such as beef and chicken, although with a lower proportion of histidine and serine [21].

In contrast, ostrich meat's fat levels (0.9-1.34\%) are much lower than those of meats such as lamb (8.79\%), beef $(4.6 \%)$ and chicken $(4.3 \%)$, and similar to those of poultry meat with a low fat content, such as turkey (1.19\%) [22]. While preliminary studies suggested a very low level of cholesterol, more recent research indicates that ostrich meat's cholesterol content is similar to that of beef and chicken, and varies depending on the cut of meat, being higher in fat from a bird's back (74.33 mg/100 g) than in fat from its breast $(49.50 \mathrm{mg} / 100 \mathrm{~g})$ [23]. Nonetheless, it is worth noting that ostrich meat has a more beneficial fatty acid profile than turkey, lamb or beef. Saturated fatty acids (SFA) make up 29.88-33.31\% of its total fatty acid content, monounsaturated fatty acids (MUFA) 35.52$39.05 \%$ and polyunsaturated fatty acids (PUFA) 27.64$34.60 \%$. More than $8 \%$ of ostrich meat's PUFA are omega-3 ( $\omega 3)$ fatty acids.

Besides being an important source of protein in the human diet, meat is a good provider of minerals, particularly iron and zinc. General analysis of ostrich meat's mineral content indicates a profile more like that of beef than of chicken, and notable levels of iron and zinc. Its iron content stands at around $2.75 \mathrm{mg} / 100 \mathrm{~g}$, superior to beef's $2.2 \mathrm{mg} / 100 \mathrm{~g}$ and chicken's $0.9 \mathrm{mg} / 100 \mathrm{~g}$. Its concentration of zinc, meanwhile, at around $3 \mathrm{mg} / 100 \mathrm{~g}$, is superior to that of any other poultry meat, although lower than that of beef sirloin (4.09 mg/100 g) and of lamb $[17,22]$. The sodium levels in ostrich meat, on the other hand, are far lower than in meats such as beef and chicken. The ostrich muscles with the highest concentration of sodium contain no more than $38.7 \mathrm{mg} / 100 \mathrm{~g}$, in comparison to $63 \mathrm{mg} / 100 \mathrm{~g}$ in the case of beef and 77 $\mathrm{mg} / 100 \mathrm{~g}$ where chicken is concerned.

Although information on ostrich meat's vitamin content is still limited, the studies undertaken to date have detected B-group vitamin levels similar to those of beef, but with higher levels of vitamins B6 (0.225 mg/100 g, compared to beef's $0.125 \mathrm{mg} / 100 \mathrm{~g}), \mathrm{B} 12$ (1.25 $\mu \mathrm{g} / 100 \mathrm{~g}$ compared to $1 \mu \mathrm{g} / 100 \mathrm{~g}$ ) and E [24].

Table 2. Average chemical composition (mg/100 g of edible material) of different types of meat

\begin{tabular}{|c|c|c|c|c|c|}
\hline Component & Ostrich $^{1}$ & Lamb $^{2}$ & Beef $^{2}$ & Chicken $^{2}$ & Turkey $^{2}$ \\
\hline Fat (g/100 g) & 1.12 & 8.79 & 4.6 & 4.3 & 1.19 \\
\hline Cholesterol & $49.5-74.33$ & 78 & $59-65$ & $69-110$ & $45-61$ \\
\hline MUFA+PUFA/SFA ${ }^{3}$ & 2.16 & 0.86 & 1.25 & 2.3 & 1.33 \\
\hline $\mathrm{Fe}$ & 2.75 & 1.8 & 2.2 & 0.9 & 0.65 \\
\hline $\mathrm{Zn}$ & 3 & 2.89 & 3.9 & 0.85 & 1.45 \\
\hline $\mathrm{Na}$ & 38.7 & 59.5 & 63 & 77 & 48.5 \\
\hline Vit. B6 & 0.225 & 0.22 & 0.125 & 0.35 & 0.5 \\
\hline Vit. B12 ( $\mu \mathrm{g} / 100 \mathrm{~g})$ & 1.25 & 1 & 1.5 & - & 1.5 \\
\hline Vit. E & $>0.1$ & 0.075 & 0.1 & 0.1 & - \\
\hline
\end{tabular}

${ }^{1}$ Polawska et al. (2011). ${ }^{2}$ Moreiras et al. (2008). ${ }^{3}$ MUFA:

monounsaturated fatty acids; PUFA: polyunsaturated fatty acids; SFA: saturated fatty acids.

Source: produced by the authors, drawing on Moreiras et al. (2008) and Polawska et al. (2011).

\subsection{Ostrich Meat Consumption: A New, Exotic African Meat in Old Europe}

Domesticated ostriches have been farmed for commercial purposes in South Africa since as long ago as the $18^{\text {th }}$ century [25], but it was not until the third quarter of the $19^{\text {th }}$ century that the practice became more developed, closely linked to feather production. Although South Africa almost completely monopolized ostrich 
farming internationally for virtually the entire $20^{\text {th }}$ century, substantial numbers of farms began to appear elsewhere in the early 1990s. As of then, countries such as Zimbabwe, Namibia and Israel also began producing and even exporting ostrich meat and its by-products (feathers, leather, eggs, etc.) [26].

There has been moderate growth in ostrich meat production and exports in the last two decades. The worldwide production level presently stands at around 12,000 to 15,000 tons. South Africa aside, global production is highly fragmented, and the list of countries involved seems to be growing steadily. South Africa still accounts for some $60 \%$ of that production and has a $75 \%$ share of the global ostrich market [27]. It should be noted, however, that the value of a slaughtered ostrich in South Africa breaks down as $45 \%$ skin (leather), $45 \%$ meat and $10 \%$ feathers. In contrast, the corresponding breakdown in Europe is $75 \%$ meat and $25 \%$ skin [27], probably due to ostrich's current popularity as a food regarded as "healthy", as mentioned earlier.

Europe's ostrich meat market is still incipient, and has largely been based on imports from elsewhere (chiefly South Africa). Today, the main European producers are Belgium, France, Italy, Portugal and Spain. Meanwhile, production is developing apace in other countries, such as Poland, Croatia and, to a lesser degree, others in the east of the continent $[25,28]$.

In the beginning ostrich meat business got by experiencing ups and downs to a greater or lesser degree. However, in the year 2000, the ostrich meat industry was able to take advantage of the socioeconomic fluctuation stemming from "mad cow disease" to present its new product to a market requiring alternatives to beef and there was a sudden rise in the consumption of ostrich meat. [29] Beef consumption recovered almost completely within little more than a year and, the consumption of ostrich meat subsequently dropped back again. Nonetheless, ostrich meat had made an important achievement, in that it was no longer "unknown” to consumers and had gained a foothold in the market of different countries in Europe. Following the initial boom and subsequent fall in its consumption, although it doesn't constitute a major volume in absolute terms, the ostrich meat has now a stable, consolidated customer base, revolving much more around restaurants than households $[13,30]$.

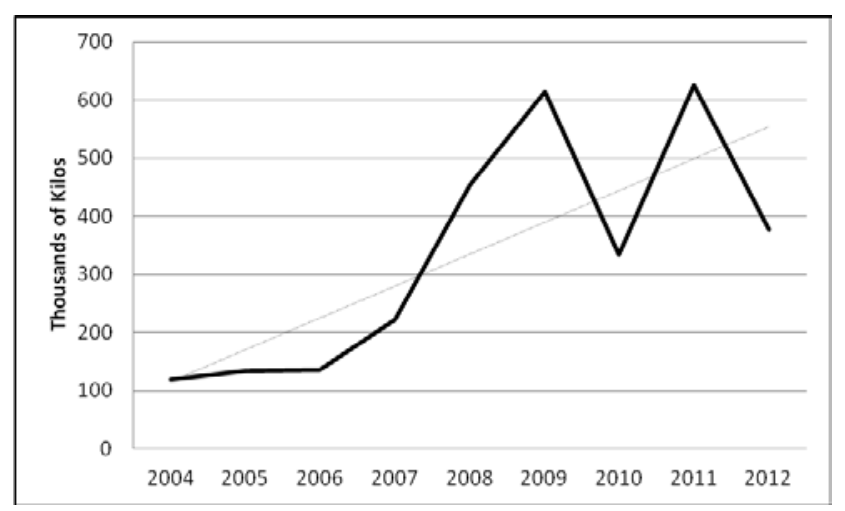

Figure 1. Evolution and trends in consumption of ostrich meat in Spain (Source: data from de Spanish Ministry of Agriculture, Food and Enviroment (2004-2012))

In addition, the present increase in ostrich farming activity could lead to another ostrich product, specifically eggs, being used for food purposes, not only in terms of direct consumption but also to industrial ends in the food sector (yolk lecithins or carotenoids, egg whites in cakes and pastries, etc.).

Chemically and nutritionally, ostrich eggs are fairly similar to chicken eggs, but with a lower level of cholesterol in their yolks (around 2 mg less) and a greater proportion of unsaturated fatty acids in relation to saturated fatty acids [31].

Nonetheless, as also applies to the bird's meat, it would be necessary to assess the potential effects of an increase in the production of ostrich eggs, as there are studies that have found that the ratio of w6 to $\mathrm{w} 3$ fatty acids is up to 10 times higher in the eggs of captive birds than in those of birds that lay them in the wild [32]. It would also be necessary to consider matters as apparently straightforward as what the recommended level of consumption would be or the number of servings a single egg should represent, bearing in mind that each ostrich egg is roughly equivalent to 24 chicken eggs.

\section{Discussion}

Given ostrich meat's aforementioned characteristics and nutritional composition, its inclusion among the regular sources of animal protein in our diet is a possibility, as it not only combines some of the benefits of poultry and red meat but also boasts a number of added values.

Eating ostrich meat might be advisable in cases of obesity or cardiovascular disease, due to its low fat content and its fatty acid profile. It has a high level of $\omega 3$ fatty acids, and more than twice the quantity of unsaturated fatty acids as of saturated fatty acids (MUFA + PUFA / SFA). Both those factors have been linked with positive effects on cardiovascular mortality and disease as a result of the combination of various protective mechanisms, including reducing serum triglyceride levels and an anti-thrombotic, anti-inflammatory, antiarrhythmic and anti-atherogenic effect [33].

Another positive aspect where the cardiovascular system is concerned is ostrich meat's low concentration of sodium. This would give it a protective effect in cases of hypertension, as a high salt intake is associated with a high prevalence of the condition in question, as well as with increased morbidity and mortality from cerebrovascular disease [1].

Moreover, ostrich meat contains greater quantities of vitamin $\mathrm{E}$ and $\mathrm{Zn}$ than other types of meat (red and poultry alike). The proven relationship between those micronutrients and antioxidant effects and functions could give ostrich meat potential benefits with regard to cancer, the cardiovascular system and the prevention of ageing [34,35,36]. Finally, its high iron and vitamin B12 content could also make it particularly recommendable in physiological situations in which a greater iron intake is required, such as pregnancy or adolescence, or in cases of anaemia [37].

However, much research is needed on the effects of regular consumption of this meat and its general effects on the body. At the moment, studies on lipid metabolism in rats have not revealed significant differences in terms of serum lipoprotein levels and liver transaminases between animals fed with ostrich meat and others fed on beef [38]. 
The effect that an increase in demand for ostrich meat could have on production (e.g. environmental impact), on farming practices (e.g. local legislation on the birds' stabling or on farming them in semi-wild conditions), on the type of feed used and on systems for the meat's production and conservation ought to be studied, as should the way in which all those considerations might affect the product's organoleptic and nutritional characteristics $[19,39]$. The economic impact where consumers are concerned should also be studied, given that, as some authors indicate, the high cost of ostrich meat may have prevented the corresponding market from expanding as might have been expected [30].

Another important aspect to bear in mind is that for a new food to be incorporated into a population's everyday diet, it must find its place in the household culinary system, in day-to-day cuisine. If it fails to do so, it will never be part of a society's eating habits, no matter how highly nutritionists recommend it or how much is spent on advertising it [40].

\section{Conclusions}

Many of the factors referred to here combine to present ostrich meat with significant opportunities in the market, both at present and in the future. Ostrich meat could secure a share of the red meat market, thus offering consumers greater variety.

Nutritionally speaking, ostrich meat could be presented as a healthier alternative to beef, due to the former's lower fat and sodium content, heart-healthy lipid profile, high concentration of iron and vitamin B12, and superior levels of zinc and vitamin E. Nonetheless, a great deal of research on the general effects that habitually eating such meat has on the body still needs to be carried out. Moreover ostrich meat still faces a significant social obstacle. Despite having made tentative inroads into the market, it is mainly consumed in restaurants rather than homes. This means that, at least for the time being, it is unlikely to become part of people's regular diet.

\section{References}

[1] WHO Europe CINDI dietary guide. Geneva, World Health Organization. 2000.

[2] Bender, A. Meat and meat products in human nutrition in developing countries. Food and Nutritional Papers 53, FAO 1992 (Accessed online on 17 December 2011 http://www.fao.org/docrep/T0562E/T0562E00.htm).

[3] Kushi, LH, Byers, T, Doyle, C, Bandera, EV, McCullough, M, Gansler, T, Andrews, KS and Thun, MJ. "American Cancer Society Guidelines on Nutrition and Physical Activity for Cancer Prevention: Reducing the Risk of Cancer With Healthy Food Choices and Physical Activity”. CA: A Cancer Journal for Clinicians, 56: 254-281. 2006.

[4] Bach-Faig, A, et al. "Mediterranean diet pyramid today. Science and cultural updates". Public Health Nutrition, 14(12A), 22742284. 2011

[5] Alexander D. et al. "A review and meta-analysis of prospective studies of red and processed meat intake and prostate cancer". Nutrition Journal, 9, 50. 2010.

[6] Norat T., et al. "Meat consumption and colorectal cancer risk: Dose-response meta-analysis of epidemiological studies". International Journal of Cancer, 98(2): 241-56. 2002.

[7] Butler, L.M., et al. "Heterocyclic amines, meat intake, and association with colon cancer in a population-based study". Am. J. Epidemiol., 157(5): 434-45. 2011
[8] Babio, N. et al. "Association between red meat consumption and metabolic syndrome in a Mediterranean population at high cardiovascular risk: Cross-sectional and 1-year follow-up assessment. Nutrition, Metabolism and Cardiovascular Diseases (NMCD). 2010.

[9] Micha R. et al. "Red and processed meat consumption and risk of incident coronary heart disease, stroke, and diabetes: A systematic review and meta-analysis”. Circulation. June 1; 121 (21): 22712283. 2010.

[10] Medina, F.X. "Cows, Pigs, and... Witches! On Meat, Diet and Food in the Mediterranean Area". Estudios del Hombre, 19: 155164. 2005.

[11] Contreras, J. "Los aspectos culturales en el consumo de carne". Gracia, M. (coord.). Somos lo que comemos. Estudios de alimentación y cultura en España. Barcelona, Ariel. 2002.

[12] Briz, J. \& De Felipe, I. "Análisis de la actitud y el comportamiento del consumidor español de carne fresca”. Cuadernos del CEAGRO, 2, p. 22. Buenos Aires. 2000.

[13] Martín Cerdeño, V.J. “ Consumo de carne y productos cárnicos: Evolución y tendencias más recientes”. Distribución y Consumo, 9, May-June. Madrid: Mercasa http://www.mercasa.es/files/multimedios/pag_005023_martin_cerdeno.pdf (consulted on November 4th 2013). 2010

[14] The Protein Puzzle. The consumption and production of meat, dairy and fish in the European Union (2011). Bilthoven / The Hague, PBL Netherlands Environmental Assessment Agency. http://www.pbl.nl/en/publications/2011/meat-dairy-and-fishoptions-for-changes-in-production-and-consumption (consulted on Otober 29th 2013).

[15] Perspectivas agrícolas 2009-2018. Paris-Rome, OECD-FAO, 2009.

[16] Agencia Española de Seguridad Alimentaria y Nutrición (AESAN). Evaluación nutricional de la población adulta española 20092010. Sobre datos de la Encuesta Nacional de Ingesta Dietética (ENIDE). Madrid: AESAN; 2011.

[17] Polawska, J, Marchewka, J, Cooper, RG, Sartowksa, K, Pomianowski, J, Józwik A, Strzalkowska N and Horbanczuk, JO. "The ostrich meat - an updated review". Animal Science Papers and Reports, 29(1-2: 5-18 and 89-97). 2011.

[18] Naude RT, Van Ragensburg, AJJ, Smit, MC, Stiemie, S, Dreyer, $\mathrm{JH}$ and Rossouw EJ "Muscle and Meat. Characteristics of Ostrich Carcass”. Animal and Dairy Research Institute Irene, South Africa (mimeograph). 1979.

[19] Sales, J. "Histological, biophysical and chemical characteristics of different ostrich muscles". Journal of Science of Food and Agriculture, 70 (1), 109-114. 1996.

[20] Majewska, D, Jakubowska, M, Ligocki, M, Tarasewicz, Z, Szczerbinska, D, Karamucki, T and Sales J. "Physicochemical characteristics, proximate analysis and mineral composition of ostrich meat as influenced by muscle”. Food Chemistry 100: 1639-1648. 2009.

[21] Sales, J. "Ostrich meat research: an update”. Proceedings of World Ostrich Congress. Warsaw, September 26-29, pp. 148-160. 2002.

[22] Karakök, SG, Ozogul, Y, Saler, M and Ozogul, F. "Proximate analysis. Fatty acid profiles and mineral contents of meats: A comparative study". Journal of Muscle Foods, 21: 210-223. 2010.

[23] Horbanczuk, JO et al. "Cholesterol content and fatty acid composition of two fat depots from slaughter ostriches (Struthio cameleus) aged 14 months”. Anim. Sci. Pap. Rep. 22: 247-251. 2004.

[24] Karklina D. \& Kivite J. "The nutritional value of ostrich meat produced in Latvia". Proceedings of the XIV World Ostrich Congress. Riga, 19-20 October, pp. 83-85. 2007.

[25] Carbajo, E. "Producción de avestruces", in $3^{\text {er }}$ Symposium Internacional Aves Corredoras, Madrid, 14-16 October (unpublished report). 2005.

[26] Benson, F \& Holle, D. “The World Ostrich Industry Today”. Blue Mountain Ostrich Nutrition E-Bulletin, 93, p. 1. 2003.

[27] A Profile of the South African Ostrich Market Value Chain Pretoria, Directorate of Marketing, Department of Agriculture, Forestry and Fisheries of the Republic of South Africa, pp. 4, 3335. 2011.

[28] Carbajo, E. “El avestruz en España”. Buxadé, C. (coord.) Producción del avestruz. Aspectos clave. Madrid, Mundiprensa. 2002.

[29] Medina, F.X. "Consumo de carne y crisis alimentarias en España”. Cuadernos del CEAgro, 4. Buenos Aires. 2003. 
[30] Castelló, A. "Paper on exotic birds". Jornadas profesionales de avicultura de carne. Valladolid. 2005.

[31] Di Meo, C, Stanco, G Cutrignelli, MI, Castaldo, S and Nizza "A. Physical and chemical quality of ostrich eggs during the laying season”. British Poultry Science, 44(3): 386-390. 2003.

[32] Surai PF \& Speake BK "The Natural Fatty Acid Compositions of Eggs of Wild Birds and the Consequences of Domestication”. Meester F. \& Watson R.R. (eds.) Wild-Type Food in Health Promotion and Disease Prevention, vol. II. New Yoirk, Humana Press, pp. 121-137. 2008.

[33] Gómez Candela, CV, Loria Kohen, LM, Bermejo López and Palma Milla S. "Evidencia científica en el consumo de omega-3 en la salud cardiovascular. Importancia de la relación omega 6/omega 3”. Alim. Nutri. Salud, 17(2): 33-40. 2010.

[34] Anderson, RA, Roussel, AM, Zouari, N, Mahjoub, S, Matheau, JM and Kerkeni A. "Potential antioxidant effects of zinc and chromium supplementation in people with type 2 diabetes mellitus”. J. Am. Coll. Nutr.: 20(3): 212-218. 2001.

[35] Ye, Z \& Song H. "Antioxidant vitamins intake and the risk of coronary heart disease: meta-analysis of cohort studies". Eur. J. Cardiovasc. Prev. Rehabil.; 15: 26-34. 2008.
[36] Llacuna, L \& Mach, N. “ Papel de los antioxidantes en la prevención del cáncer”. Rev. Esp. Nutr. Hum. Diet. 16(1): 16-24. 2012.

[37] Hernández Ruiz de Eguílaz, M, Panizo, C, Navas-Carretero, S and Martínez J.A "Anemia ferropénica: estrategias dietéticas para su prevención”. Actividad Dietética, 14(2): 67-71. 2010.

[38] Carvalho-Filho, EV; Costa MJ; Bion FM and Silva JA. "Effect of the daily consumption of ostrich and bovine meat on the lipid metabolism in rats”. Ciênc. Tecnol. Aliment. 31(1), pp. 72-77. 2011.

[39] Bingol, E.B \& Ergun, O. "Effects of modified atmosphere packaging (MAP) on the microbiological quality and shelf life of ostrich meat”. Meat Science, 88(4). 774-785. 2011.

[40] González Turmo I., "Alimentación y patrimonio: ayer y hoy". Fernández de Paz, E. \& Agudo, J. (coord.) Patrimonio cultural y museología. Santiago de Compostela, Federación de Asociaciones de Antropología del Estado Español/Asociación Galega de Antropoloxía, p. 145.1999. 